\title{
Evaluation of Surface Physical Properties of Acrylic Resins for Provisional Prosthesis
}

\author{
Sérgio Paulo Hilgenberg ${ }^{\mathrm{a}}$, Emigdio Enrique Orellana-Jimenez, Wilmer Fabian Sepúlveda-Navarro ${ }^{\mathrm{b}}$,

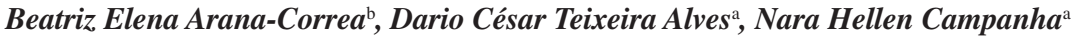 \\ a'Departamento de Odontologia, Campus Uvaranas, \\ Universidade Estadual de Ponta Grossa - UEPG, \\ Rua Gal. Carlos Cavalcanti, 4748, 84030-900 Ponta Grossa - PR, Brazil \\ ${ }^{\mathrm{b}}$ Avenida 10E, n. 5N-135, Santa Lucia, Cúcuta - Norte de Santander, Colombia
}

Received: October 10, 2007; Revised: August 13, 2008

\begin{abstract}
Acrylic resins used for provisional prostheses should have satisfactory superficial characteristics in order to ensure gingival health and low bacterial attachment. The purpose of the present study was to evaluate the superficial roughness and contact angle after two types of polishing and the Vickers hardness of three acrylic resins (Duralay - G1, Dencrilay - G2, and Dencor - G3), all shade 66, indicated for provisional fixed prostheses. Five $20 \times 3 \pm 1 \mathrm{~mm}$ diameter discoid specimens were obtained for each group. One side of the specimens was subjected to standard polishing (pumice and whiting slurry), and the opposite side was polished with special tips. The mean roughness and contact angles of the materials were measured. The specimens were subjected to the Vickers microhardness test, which indicated that standard polishing produced a surface roughness equivalent to that of the special tips. The contact angles obtained with the standard polishing were equivalent to those observed in the special tips group. The microhardness of G1 and G3 resins showed statistical differences.
\end{abstract}

Keywords: dental polishing, dental restoration, temporary, surface properties, hardness

\section{Introduction}

In rehabilitation with fixed partial prostheses, provisional prostheses made of acrylic resins provide important conditions for gingival integrity and functional and aesthetic preservation for the patient. The surface characteristics of roughness, hardness and surface free energy affect the aesthetic appearance, color stability, preservation of intermaxillary relations, bacterial attachment and visible biofilm formation ${ }^{1}$. If the material and the technique are adequate, the final result will be satisfactory quality and, hence, integrity of dental supporting tissues.

The lack of attachment of dental bacterial plaque is essential for the success of provisional fixed prostheses, which in turn is an important factor in the success of definitive fixed prostheses, from the standpoint of gingival health the provisional prosthesis should ensure. Dental materials with rough surfaces have been found to favor bacterial attachment and hinder their removal by natural forces ${ }^{2}$ or even by oral hygiene methods ${ }^{3}$. This finding has also been confirmed by Radford et al. ${ }^{4}$ and Taylor et al. ${ }^{5}$, who found greater bacterial attachment on rougher surfaces.

The surface roughness of provisional crowns depends on the type of acrylic resin employed, as well as the processing technique ${ }^{6}$ and the type of surface polishing ${ }^{7,8}$. Differences in polishing techniques have been found to interfere in roughness ${ }^{9,10,11}$. Rahal et al. ${ }^{10}$, who evaluated the effects of chemical and mechanical polishing on roughness in four types of acrylic resins used in prosthetic bases, found that mechanical polishing produced better results. Xavier et al. ${ }^{12}$ also evaluated the effect of chemical and mechanical polishing on the surface roughness of three acrylic resins from different manufacturers and concluded that mechanical polishing produced the lowest roughness values, followed by the control group and by chemical polishing. Other studies indicate that different types of polishing interfere in roughness ${ }^{13,14,15,16}$, and also lead to loss of dental material ${ }^{17}$.
Surface energy, another physical property of material, is related with the contact angle formed in the presence of liquid on the surface ${ }^{18}$. It is also related to the amount of bacteria attached to the surface of the material. However, some authors ${ }^{19,20}$ consider that the most relevant issue is the low surface roughness achieved by polishing ${ }^{21}$.

With regard to provisional fixed prostheses, the preservation of the position of the prepared tooth and healthy periodontal tissues are indispensable. The surface microhardness can serve as a density indicator, and the denser the material the more resistant to deterioration its surface $^{22}$. Therefore, in addition to the aforementioned properties, the surface property of microhardness was evaluated here as an indicator of the wear resistance of the materials under study ${ }^{18}$.

Several studies have evaluated the surface roughness, contact angle and surface microhardness of dental materials. However, the literature lacks studies of these surface physical properties in acrylic resins used specifically in provisional prostheses. Furthermore, the importance of these characteristics underlines the need for studies comparing different brands, both national and imported, to provide dentists with criteria and a scientific basis upon which to make the best possible choice of the products to be used. Therefore, the purpose of this study was to evaluate the surface physical properties of acrylic resins used in provisional prostheses following the application of different polishing techniques.

\section{Materials and Methods}

\subsection{Specimen fabrication}

This study involved three self-curing acrylic resins for provisional prostheses: G1 - Duralay (Duralay, Reliance Dental Mfg. Co., 
Chicago, EUA); G2 - Dencrilay (Dencril Com e Ind de Plasticos Ltda, Brazil); and G3 - Dencor (Clássico, São Paulo, Brazil), all of color number 66. For each group, five disk-shaped specimens measuring $20 \times 3 \pm 1 \mathrm{~mm}$ diameter were prepared and polymerized following the manufacturers' instructions.

\subsection{Surface roughness measurements}

The specimens were subjected to an initial surface roughness test $(\mathrm{Ra}-\mu \mathrm{m})$ to determine the initial parameter for comparison. They were then finished with 150 to 600 grit waterproof sandpaper under flowing water (Aropol E. Arotec, SP, Brazil) at a standard speed of $300 \mathrm{rpm}$ until they reached a thickness of $3.0 \pm 1.0 \mathrm{~mm}$. One of the surfaces was machine polished with pumice and water, followed by whiting slurry with polishing cloths (conventional or standard polishing) and the other side was polished with special tips $\left(\mathrm{Tec}^{\circledR}\right.$, São Paulo, Brazil). The specimens were then measured with a profile meter (Mitutoyo ${ }^{\circledR}$ - Surf Test 301 ) calibrated for a $0.25 \mathrm{~mm}$ sample surface. The roughness of each specimen was measured twice and the mean value recorded.

\subsection{Contact angle measurements}

To measure the contact angles, each specimen was wetted with $10 \mu \mathrm{l}$ of distilled water applied with a micropipette from a standard height of $2 \mathrm{~cm}$ above the polished surface. At this point, photographic records were made in triplicate using a digital camera (Sony Cybershot DSC - F717) situated at a distance of $20 \mathrm{~cm}$ from the pipette tip, and the images were analyzed with the Image Tool 3.0 UTHSCSA program.

\subsection{Vickers hardness measurements}

The Vickers hardness (VHN) was measured with a microhardness tester (HMV Shimadzu, Tokio, Japan), with a $0.1 \mathrm{~N}$ indenter load/15 seconds. Eight microhardness measurements were taken from each specimen.

\section{Statistical Analysis}

The surface roughness and contact angle data were subjected separately to two-way ANOVA $(\alpha=0.05)$ and Tukey $(\alpha=0.05)$ tests to compare the results of each acrylic resin brand and polishing condition. The Vickers hardness was analyzed by one-way ANOVA $(\alpha=0.05)$ and Tukey's $(\alpha=0.05)$ test to compare the results of each acrylic resin brand.

\section{Results}

Figure 1 depicts the mean values and standard deviations of the surface roughness. The unpolished specimens showed the following results: $\mathrm{G} 1=0.87 \pm 0.7 \mu \mathrm{m}, \mathrm{G} 2=0.95 \pm 1.1 \mu \mathrm{m}$ and $\mathrm{G} 3=4.2 \pm 1.9 \mu \mathrm{m}$. The group polished with slurry group yielded the following values: $\mathrm{G} 1=0.06 \pm 0.02 \mu \mathrm{m}, \mathrm{G} 2=0.06 \pm 0.02 \mu \mathrm{m}$ and $\mathrm{G} 3=0.50 \pm 0.48 \mu \mathrm{m}$, while the cup-polished group showed: $\mathrm{G} 1=0.11 \pm 0.04 \mu \mathrm{m}, \mathrm{G} 2=0.26 \pm 0.19 \mu \mathrm{m}$ and G3 $=0.2 \pm 0.09 \mu \mathrm{m}$. No statistically significant differences were found between the types of polishing, but the slurry-polished specimens showed a statistically significant difference between groups G1 and G3 $(p<0.05)$ and G2 and G3 $(\mathrm{p}<0.05)$ (Table 1).

Figure 2 shows the mean values and standard deviations of the contact angle measurements. The specimens subjected to standard polishing showed the following values: $\mathrm{G} 1=68.3 \pm 4.4^{\circ}$, $\mathrm{G} 2=69.4 \pm 9.3^{\circ}$, and $\mathrm{G} 3=62.3 \pm 7^{\circ}$, while the cup-polished specimens showed: $\mathrm{G} 1=68.3 \pm 9^{\circ}, \mathrm{G} 2=66.3 \pm 5.4^{\circ}$ and $\mathrm{G} 3=60.8 \pm 7^{\circ}$. The different polishing techniques yielded no statistically significant

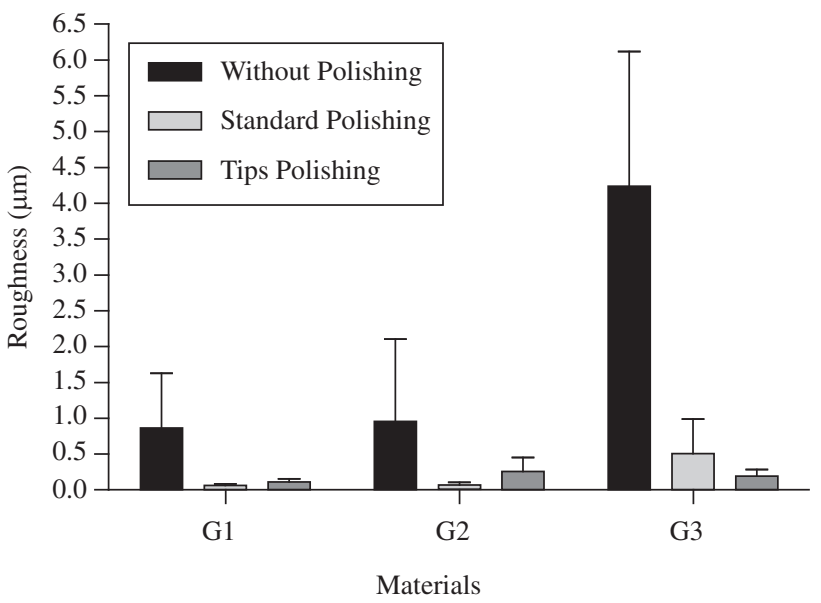

Figure 1. Mean values and standard deviation of surface roughness $(\mu \mathrm{m})$ of the materials studied.

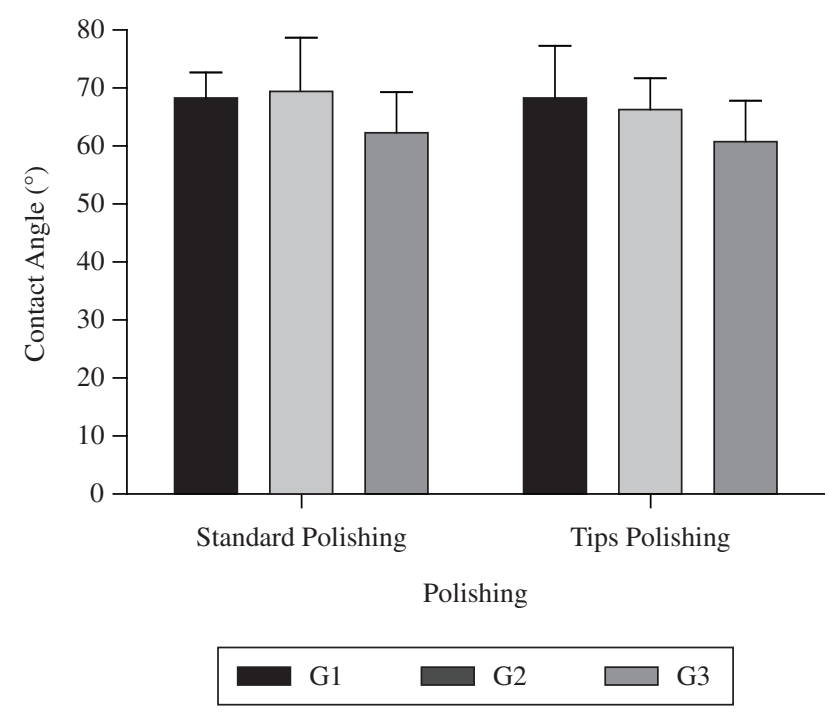

Figure 2. Mean values and standard deviation of contact angle $\left(^{\circ}\right)$ of the materials studied.

Table 1. Mean values and standard deviation of surface roughness of groups $(\mu \mathrm{m})$, according to the surface treatment.

\begin{tabular}{cccc}
\hline Group & \multicolumn{3}{c}{ Surface treatment } \\
\cline { 2 - 4 } & $\begin{array}{c}\text { Without } \\
\text { Polishing }\end{array}$ & $\begin{array}{c}\text { Polishing } \\
\text { with slurry }\end{array}$ & $\begin{array}{c}\text { Polishing } \\
\text { with cup }\end{array}$ \\
\hline G1 & $0.87 \pm 0.70$ & $0.06 \pm 0.02$ & $0.11 \pm 0.04$ \\
G2 & $0.95 \pm 1.10$ & $0.06 \pm 0.02$ & $0.26 \pm 0.19$ \\
G3 & $4.20 \pm 1.90$ & $0.50 \pm 0.48$ & $0.20 \pm 0.09$ \\
\hline
\end{tabular}

difference $(p<0.46)$ in the resins evaluated here. Furthermore, no statistically significant difference $(p<0.11)$ was found between the contact angles of the resins as a function of the polishing techniques (Table 2).

Figure 3 depicts the mean values and standard deviations of the surface microhardness. G1 showed a mean value of $15.45 \pm 0.47 \mathrm{HV}$, $\mathrm{G} 2$ of $14.89 \pm 0.49 \mathrm{HV}$, and G3 of $14.38 \pm 0.28 \mathrm{HV}$. The G1 and G3 materials showed statistically significant differences $(p<0.01)$ in surface microhardness (Table 2). 


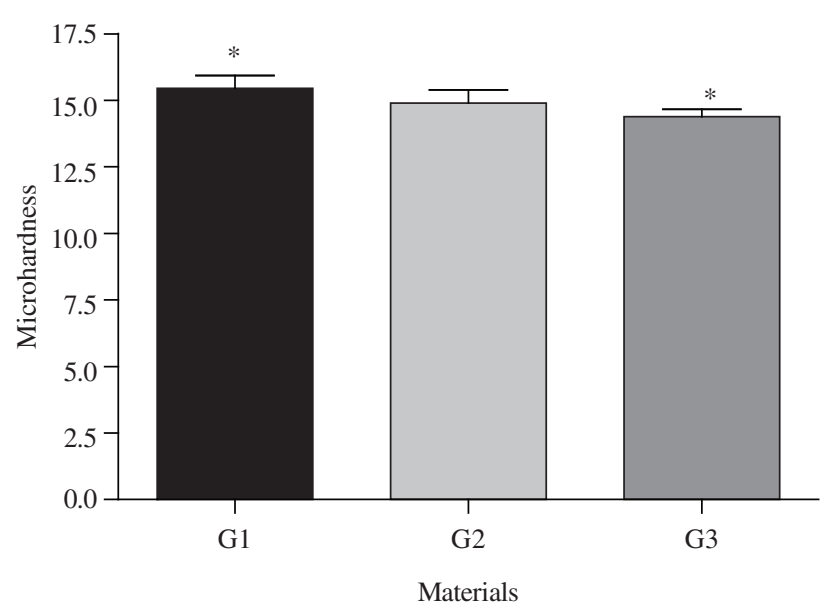

Figure 3. Mean values and standard deviation of Vickers microhardness (MHV) of the materials studied. (*) Significant statistical differences

Table 2. Mean results and standard deviation of Contact Angles $\left({ }^{\circ}\right)$ and Vickers hardness (VHN) of the materials studied.

\begin{tabular}{|c|c|c|c|}
\hline \multirow[t]{2}{*}{ Group } & \multicolumn{3}{|c|}{ Properties } \\
\hline & $\begin{array}{c}\text { Contact angle }\left({ }^{\circ}\right) \\
\text { (polishing } \\
\text { with slurry) }\end{array}$ & $\begin{array}{c}\text { Contact angle }\left(^{\circ}\right) \\
\text { (polishing with cup) }\end{array}$ & $\begin{array}{l}\text { Vickers } \\
\text { hardness } \\
(\mathrm{VHN})\end{array}$ \\
\hline G1 & $68.3 \pm 4.4$ & $68.3 \pm 9^{\circ}$ & $15.45 \pm 0.47$ \\
\hline $\mathrm{G} 2$ & $69.4 \pm 9.3$ & $66.3 \pm 5.4^{\circ}$ & $14.89 \pm 0.49$ \\
\hline G3 & $62.3 \pm 7^{\circ}$ & $60.8 \pm 7^{\circ}$ & $14.38 \pm 0.28$ \\
\hline
\end{tabular}

\section{Discussion}

The surface roughness of dental materials considered clinically ideal by Quirynen et al. ${ }^{19}$ and Bollen et al. ${ }^{23}$ is close to $0.2 \mu \mathrm{m}$ or less. All the groups in the present study presented a surface roughness that exceeded this parameter when the specimens were left unpolished, demonstrating that an unpolished provisional fixed prosthesis is unacceptable. After polishing with slurry, the measured roughness of G1 and G2 was lower $(0.06 \mu \mathrm{m})$, although that of G3 was higher than the ideal $(0.50 \mu \mathrm{m})$. According to Berger et al. ${ }^{7}$, self-curing acrylic resins should be polished using the standard polishing technique (pumice and whiting slurry). However, our results indicate that the G3 material is clinically unsuitable if subjected only to the standard polishing procedure.

In the cup-polished group, only G1 presented an ideal surface $(0.11 \mu \mathrm{m})$. The slight variation of $0.2 \mu \mathrm{m}$ was negligible, since the cytotoxicity of monomers may have an antibacterial effect on microbiota on the surface of the material ${ }^{23}$. According to Campanha et al. ${ }^{24}$, residual monomers may have a cytotoxic effect on a number of cells. Hence, further studies about the attachment of bacteria on such surfaces are needed.

In our study, however, the superficial roughness of polished surfaces decreased significantly in relation to that of the unpolished ones. This greater smoothness should help reduce the attachment of bacteria and maintain periodontal integrity, regardless of the polishing technique employed. Furthermore, to improve surface quality, Mantikos et al. ${ }^{25}$ propose the application of a layer of glaze, claiming that in provisional restorations, this procedure is indicated to reduce bacterial attachment. However, Sesma et al. ${ }^{26}$ demonstrated that glaze applied on definitive surfaces did not prevent bacterial attachment, although it aided its removal.
Several authors ${ }^{27,28,29,30}$ have stated the importance of choosing adequate parameters for surface roughness measurements. Because the Ra parameter is limited to horizontal measurements ${ }^{27,28,29}$, different surfaces could present the same roughness values, thus rendering the results questionable. Nevertheless, since this parameter is a routine method $^{1,14,15,16,17,30}$, it was adopted here to facilitate comparisons with previous studies.

The contact angle created between the water and the acrylic resin should be, on average, $75^{\circ[31]}$. This is an important property, for it indicates the saliva's ability to flow over the surface of a material. In this study, after the application of both polishing techniques, all the groups presented mean contact angles lower than but very close to $75^{\circ}$. Since no statistically significant differences were found between the contact angles resulting from the two polishing techniques, or between the resin brands, this value was considered acceptable for the good superficial energy presented by the three acrylic resin brands.

The Vickers microhardness test is based on the ability of the surface of any material to resist the penetration of a specific tip with a given load for a specific time. In our study, the surface hardness of the G1 and G3 materials showed differences. The mean microhardness values (15.45 HV; $14.89 \mathrm{HV}$ and $14.38 \mathrm{HV}$ ) of the materials evaluated here were lower than those assessed by Pavarina et al. ${ }^{11}$ (17.0 HV and 16.6 HV) in artificial teeth used in complete prostheses, and lower than those reported by Campanha et al. ${ }^{24}$, even when the teeth were subjected to sterilization cycles, which could reduce their surface hardness. Although artificial teeth and the materials used in provisional prostheses are made of acrylic resins, the greater hardness of artificial teeth is probably attributable to the fabrication process, since the conditions for handling and polymerizing these materials in an industrial environment enhances their physical and mechanical properties.

\section{Conclusions}

Within the limitations of this in vitro study, and based on the present methodology, the following conclusions were drawn

1. The two polishing techniques yielded similar surface roughness results. However, in the group polished with slurry (standard polishing), G3 displayed greater surface roughness than G1 and $\mathrm{G} 2$;

2. The polishing methods did not affect the contact angle of the materials tested here;

3. No differences were observed in the contact angles of the various materials subjected to the two polishing techniques; and

4. G1 showed higher mean Vickers hardness values than G3.

\section{Acknowledgements}

The authors gratefully acknowledge the financial support of the Brazilian research funding agency CAPES.

\section{References}

1. Ulusoy M, Ulusoy N, Aydin AK. An evaluation of polishing techniques on surface roughness of acrylic resins. The Journal of Prosthetic Dentistry. 1986; 56(1):107-112.

2. Verran J, Maryan CJ. Retention of Candida albicans on acrylic resin and silicone of different surface topography. The Journal of Prosthetic Dentistry. 1997; 77(5):535-539.

3. Quirynen M, Bollen CM. The influence of surface roughness and surface free energy on supra- and subgingival plaque formation in man. A review of the literature. Journal of Clinical Periodontology. 1995; 22(1):1-14.

4. Radford DR, Sweet SP, Challacombe SJ, Walter JD. Adherence of Candida albicans to denture-base materials with different surface finishes. Journal of Dentistry. 1998; 26(7):577-583. 
5. Taylor R, Maryan C, Verran J. Retention of oral microorganisms on cobalt-chromium alloy and dental acrylic resin with different surface finishes. The Journal of Prosthetic Dentistry. 1998; 80(5):592-597.

6. Zissis AJ, Polyzois GL, Yannikakis SA, Harrison A. Roughness of denture materials: a comparative study. The International Journal of Prosthodontics. 2000; 13(2):136-140.

7. Berger JC, Driscoll CF, Romberg E, Luo Q, Thompson G. Surface roughness of denture base acrylic resins after processing and after polishing. Journal of Prosthodontics. 2006; 15(3):180-186.

8. Alves PV, Lima-Filho RM, Telles E, Bolognese A. Surface roughness of acrylic resins after different curing and polishing techniques. The Angle Orthodontist. 2007; 77(3):528-531.

9. Saito SK, Lovadino JR, Kroll LB. Rugosidade e pigmentação superficial de materiais ionoméricos. Pesquisa Odontológica Brasileira. 2000; 14(4):351-356.

10. Rahal JS, Mesquita MF, Henriques GEP, Nobilo MAA. Surface roughness of acrylic resins submitted to mechanical and chemical polishing. Journal of Oral Rehabilitation. 2004; 31(11):1075-1079.

11. Pavani RC, Lazarin AA, Machado AL, Vergani CE, Giampaolo ET, Pavarina AC. A rugosidade de materiais reembasadores rígidos submetidos à irradiação por microondas. Brazilian Oral Research. 2006; 20(Ia184):80. (Supplement Resumo)

12. Xavier ACC, Morais AALO, Kimpara ET, Paes-Junior TJA, Borges ALS, Pereira SMB, Chaves CA. Avaliação da rugosidade superficial de resinas acrílicas sob três tratamentos de superfície. Brazilian Oral Research. 2006; 20(Ia124):73. (Supplement Resumo).

13. Ribeiro BCI, Oda M, Matson E. Avaliação da rugosidade superficial de três resinas compostas submetidas a diferentes técnicas de polimento. Pesquisa Odontolológica Brasileira. 2001 jul./set.; 15(3):252-256.

14. Cunha LG, Alonso RCB, Santos PH, Sinhoreti MAC. Comparative study of the surface roughness of Ormocer-based and conventional composites. Journal of Oral Science. 2003; 11(4):348-353.

15. Nagem-Filho H, D'Azevedo MTFS, Nagem HD, Marsola FP. Surface roughness of composite resins after finishing and polishing. Brazilian Dental Journal. 2003; 14(1):37-41

16. Barbosa SH, Zanata RL, Navarro MFL, Nunes OB. Effect of different finishing and polishing techniques on the surface roughness of microfilled, hybrid and packable composite resins. Brazilian Dental Journal. 2005; 16(1):39-44.

17. Garcia FCP, Wang L, D’Alpino PHP, Souza JB, Araújo PA, Mondelli RFL. Evaluation of the roughness and mass loss of the flowable composites after simulated toothbrushing abrasion. Brazilian Oral Research. 2004; 18(2):156-161.
18. Anusavice KJ. (Ed.). Phillip's science of dental materials. 10 ed. Philadelphia: WB Saunders; 1996. p. 69-71.

19. Quirynen M, Marechal M, Busscher HJ, Weerkamp AH, Darius PL, Van Steenberghe D. The influence of surface free energy and surface roughness on early plaque formation. An in vivo study in man. Journal of Clinical Periodontology. 1990; 17(3):138-144.

20. Hannig M. Transmission electron microscopy of early plaque formation on dental materials in vivo. European Journal of Oral Sciences. 1999; 107(1):55-64.

21. Nishioka M, Yamabe Y, Hisatsune K, Fujii H. Influence of polishing of denture base resin and metal surfaces on wettability with water and saliva. Dental Materials Journal. 2006; 25(1):161-165.

22. Diaz-Arnold AM, Dunne JT, Jones AH. Microhardness of provisional fixed prosthodontic materials. The Journal of Prosthetic Dentistry.1999; 82(5):525-528.

23. Bollen CML, Lambrechts P, Quirynen M. Comparison of surface roughness of oral hard materials to the threshold surface roughness for bacterial plaque retention: a review of the literature. Dental Materials. 1997; 13(4):258-259.

24. Campanha NH, Pavarina AC, Vergani CE, Machado AL. Effect of microwave sterilization and water storage on the Vickers hardness of acrylic resin denture teeth. The Journal of Prosthetic Dentistry. 2005; 93(5):483-487.

25. Mantzikos T, Epstein M. Interior surface sealant for acrylic appliances. Journal of Clinical Orthodontics. 1998; 32(3):152-153.

26. Sesma N, Lagana DC, Morimoto S, Gil C. Effect of denture surface glazing on denture plaque formation. Brazilian Dental Journal. 2005; 16(2):129-134.

27. Leitão J, Hegdhal T. On the measuring of roughness. Acta odontologica Scandinavica. 1981; 39:379-384.

28. Whitehead SA, Shearer AC, Watts DC, Wilson NH. Comparison of methods for measuring surface roughness of ceramic. Journal of Oral Rehabilitation. 1995; 22(6):421-427.

29. Whitehead AS, Shearer AC, Watts DC. Surface texture changes of a composite brushed with tooth whitening dentifrices. Dental Materials. 1996; 12(5):315-318.

30. Mondelli RFL, Wang L, Garcia FCP, Prakki A, Mondelli J, Franco $\mathrm{EB}$, Ishikiriama A. Evaluation of weight loss and surface roughness of compomers after simulated toothbrushing abrasion test. Journal of Applied Oral Science. 2005; 13(2):131-135.

31. Craig RG, Powers JM. Materiais Dentários Restauradores. 11 ed. São Paulo: Livraria Editora Santos; 2004. 704 p. 